Agnieszka Tomaszewska

\title{
Ocena możliwości łączenia mandatu posła ze statusem komandytariusza w spółce komandytowej $^{1}$
}

\author{
Assessment of the possibility of combining a Deputy's mandate \\ with the status of a limited partner in a limited partnership
}

\begin{abstract}
In the opinion of the author, there are no obstacles to combine the mandate of a Deputy with the status of a limited partner in a limited partnership, in case, in addition to the Deputy the company is to include another limited partner (natural person) and the limited liability company as a general partner, and in a limited liability company the Deputy will neither be a partner, nor will perform any functions related to decision making, and such a limited partnership will be represented only by the general partner.
\end{abstract}

Keywords: limited partnership, Deputy, mandate

\begin{abstract}
W ocenie autorki opinii brak jest przeszkód do łączenia mandatu posła ze statusem komandytariusza w spółce komandytowej, kiedy w skład spółki oprócz posła ma wejść jeszcze jeden komandytariusz (osoba fizyczna) oraz spółka z o.o. jako komplementariusz, a w spółce z o.o. poseł nie będzie wspólnikiem ani nie będzie pełnił żadnych funkcji związanych z podejmowaniem decyzji, zaś tę spółkę komandytową będzie reprezentował wyłącznie komplementariusz.
\end{abstract}

Słowa kluczowe: spółka komandytowa, poseł, mandat

Ekspert ds. legislacji Biura Analiz Sejmowych •

Kancelaria Sejmu, Biuro Analiz Sejmowych, Wydział Analiz Prawnych, Zespół Prawa

Prywatnego, WARSZAWA, POLSKA .

agnieszka.tomaszewska@sejm.gov.pl • https://orcid.org/0000-0001-9524-8671

\section{Przedmiot opinii}

Opinia dotyczy odpowiedzi na pytanie o możliwość łączenia mandatu posła ze statusem komandytariusza w spółce komandytowej. Chodzi o wyjaśnienie sytuacji, w której poseł może się znaleźć: $w$ skład spółki oprócz mnie wejdzie jeszcze jeden komandytariusz (osoba fizyczna) oraz spółka z o.o. jako komplementariusz. $W$ spółce $z$ o.o. nie będę wspólnikiem ani nie będę pełnit żadnych funkcji (nie będę ani członkiem zarzadu ani prokurentem) i nie będę miał żadnego wplywu na podejmowane przez komplementariusza decyzje. Ponadto spótkę komandytową będzie

1 Opinia prawna $w$ sprawie możliwości łączenia mandatu posła ze statusem komandytariusza w spółce komandytowej sporządzona 3 lutego 2020 r. na zlecenie posła Koalicyjnego Klubu Parlamentarnego Lewicy (Razem, Sojusz Lewicy Demokratycznej, Wiosna Roberta Biedronia); BAS-WAP 328/19. 
reprezentował wyłacznie komplementariusz. Komandytariusze nie będa upowaznieni do jej reprezentowania. Nie będę także prokurentem spółki komandytowej.

Opinia uwzględnienia stan prawny na dzień 19 grudnia $2019 \mathrm{r}$.

W opinii uwzględniono postanowienia następujących aktów prawnych:

- ustawa z 9 maja 1996 r. o wykonywaniu mandatu posła i senatora, t.j. Dz.U. 2018, poz. 1799; dalej: u.w.m.p.s.,

- ustawa z 15 września 2000 r. - Kodeks spółek handlowych, t.j. Dz.U. 2019, poz. 505, ze zm.; dalej: k.s.h.,

- ustawa z 6 marca 2018 r. - Prawo przedsiębiorców, t.j. Dz.U. 2019, poz. 1292; dale: u.p.p.);

- ustawa z 21 sierpnia 1997 r. o ograniczeniu prowadzenia działalności gospodarczej przez osoby pełniące funkcje publiczne, t.j. Dz.U. 2017, poz. 1393, ze zm.; dalej: ustawa o ograniczeniu prowadzenia działalności gospodarczej przez osoby pełniące funkcje publiczne,

- ustawa z 5 czerwca 1998 r. o samorządzie województwa, t.j. Dz.U. 2019, poz. 512, ze zm.; dalej: u.s.w.

\section{Uzasadnienie}

Spółka komandytowa jest spółką osobową (art. $4 \$ 1$ k.s.h.; art. 102 k.s.h.), w której nie występuje kapitał zakładowy. Spółka osobowa, mimo że nie ma osobowości prawnej, została wyposażona w zdolność prawną i może we własnym imieniu nabywać prawa, zaciągać zobowiązania, pozywać i być pozywana (art. 8 $\$ 1$ k.s.h.). Spółka komandytowa ma na celu prowadzenie przedsiębiorstwa pod własną firmą, w której wobec wierzycieli za zobowiązania spółki co najmniej jeden wspólnik odpowiada bez ograniczenia (komplementariusz), a odpowiedzialność co najmniej jednego wspólnika (komandytariusza) jest ograniczona (art. 102 k.s.h.). Spółka komandytowa nie ma organów takich jak zarząd czy rada nadzorcza.

Dopuszczalność łączenia mandatu posła ze statusem komandytariusza spółki komandytowej należy ocenić na tle art. 34 ust. 1 i 2 u.w.m.p.s., tj. przepisów formułujących nakazy niepołączalności materialnej. Zgodnie z ust. 1 tego artykułu: [p] osłowie i senatorowie nie moga prowadzić działalności gospodarczej na własny rachunek lub wspólnie z innymi osobami z wykorzystaniem mienia państwowego lub komunalnego, a także zarządzać taka działalnościa lub być przedstawicielem czy pełnomocnikiem $w$ prowadzeniu takiej działalności. Z kolei ust. 2 przewiduje, że: [p]osłowie i senatorowie nie moga być członkami władz zarządzajacych lub kontrolnych i rewizyjnych ani petnomocnikami handlowymi przedsiębiorców $z$ udziałem państwowych lub komunalnych osób prawnych lub przedsiębiorców, w których uczestnicza takie osoby. Wybór lub powołanie posła lub senatora do tych władz jest $z$ mocy prawa nieważny. 
Ponieważ w przypadku spółki komandytowej nie można mówić o występowaniu władz zarządzających lub kontrolnych i rewizyjnych ${ }^{2}$, aktywność posła w spółce komandytowej powinna być oceniana przede wszystkim z perspektywy art. 34 ust. 1 u.w.m.p.s. Mając powyższe na uwadze, należy w pierwszej kolejności ustalić, jaki jest status komandytariusza spółki komandytowej i czy może być on uznany za osobę „prowadzącą działalność gospodarczą na własny rachunek lub wspólnie z innymi osobami” lub „zarządzającą taką działalnością” oraz czy może on wykonywać czynności jako przedstawiciel czy też pełnomocnik.

Co do zasady uczestnictwo komandytariusza w spółce komandytowej ma charakter bierny. To komplementariusz jest wspólnikiem aktywnym, prowadzącym sprawy spółki i reprezentującym spółkę na zewnątrz. Natomiast zgodnie $\mathrm{z}$ art. $123 \$ 1$ k.s.h.: [k]omandytariusz uczestniczy w zysku spółki proporcjonalnie do jego wkładu rzeczywiście wniesionego do spółki, chyba że umowa spółki stanowi inaczej. Z kolei w art. $121 \$ 1$ k.s.h. wskazano, że: [k]omandytariusz nie ma prawa ani obowiązku prowadzenia spraw spółki, chyba że umowa spółki stanowi inaczej. Ponadto przepisy ustawowe wprowadzają ograniczenia dotyczące możliwości reprezentowania spółki przez komandytariusza. Zgodnie z art. 117 k.s.h.: [s]półkę reprezentują komplementariusze, których z mocy umowy spółki albo prawomocnego orzeczenia sadu nie pozbawiono prawa reprezentowania spółki. Jak stanowi art. $118 \$ 1$ k.s.h.: [k]omandytariusz może reprezentować spółkę jedynie jako pełnomocnik. Z powyższego wynika zatem, że, co prawda, komandytariusz może reprezentować spółkę komandytową jako jej pełnomocnik (lub prokurent art. $109^{1} \$ 1$ k.c. $\left.^{3}\right)$, to, co do zasady jednak, spółka komandytowa jest reprezentowana przez komplementariusza, który uprawnienie do reprezentacji nabywa z mocy prawa z chwilą uzyskania statusu wspólnika-komplementariusza.

Zgodnie $\mathrm{z}$ art. 3 u.p.p.: [d] ziałalnościa gospodarcza jest zorganizowana działalność zarobkowa, wykonywana we własnym imieniu i w sposób ciagły. Przy czym dla oceny, czy dana aktywność jest działalnością gospodarczą, kluczowe znaczenie ma to, czy faktycznie wykonywana aktywność spełnia - określone w art. 3 u.p.p. materialne przesłanki uznania jej za działalność gospodarczą. Z kolei jak stanowi art. 4 ust. 1-2 u.p.p.: [p]rzedsiębiorca jest osoba fizyczna, osoba prawna lub jednostka organizacyjna niebędaca osoba prawna, której odrębna ustawa przyznaje zdolność prawna, wykonująca działalność gospodarcza, a także wspólnicy spółki cywilnej w zakresie wykonywanej przez nich działalności gospodarczej. Na grun-

2 R. Dubowski, Opinia prawna w sprawie łaczenia mandatu posła łaczenia mandatu $z$ etatem i działalnościa gospodarcza (poset-elekt Aleksander Miszalski), opinia z 7 listopada 2019 r., BAS-WAP 2184/19.

3 Prokura jest petnomocnictwem udzielonym przez przedsiębiorce podlegającego obowiązkowi wpisu do Centralnej Ewidencji i Informacji o Działalności Gospodarczej albo do rejestru przedsiębiorców Krajowego Rejestru Sądowego, które obejmuje umocowanie do czynności sądowych i pozasądowych, jakie sq zwiazane z prowadzeniem przedsiębiorstwa. 
cie tych przepisów przedsiębiorcą jest więc spółka osobowa, która jest jednostką organizacyjną mającą zdolność prawną, a nie jej wspólnik. Jedynie w przypadku spółki cywilnej za przedsiębiorców należy uznać wspólników, a nie samą spółkę. Należy zatem uznać, że komandytariusz nie jest przedsiębiorcą i nie prowadzi działalności gospodarczej ani samodzielnie, ani wspólnie z innymi osobami.

Biorąc pod uwagę powyższe, wydaje się, że zakwalifikowanie uczestnictwa w spółce osobowej jako „prowadzenie działalności gospodarczej wspólnie z innymi osobami”, na gruncie art. 34 ust. 1 u.w.m.p.s., może budzić wątpliwości. W literaturze przedmiotu podkreśla się, że: wspólne z innymi osobami prowadzenie działalności gospodarczej to $w$ aktualnych warunkach nic innego, jak prowadzenie działalności $w$ formie spółki cywilnej. ${ }^{4}$ Co więcej: nie może być mowy o wspólnym prowadzeniu działalności gospodarczej przez wspólników, np. w spółkach osobowych, jawnej w szczególności. To spótka prowadzi działalność gospodarcza na własny rachunek jako przedsiębiorca. Jest to konsekwencja przyjęcia podmiotowości prawnej podmiotów ustawowych (jednostek nieposiadających osobowości prawnej) $)^{5}$. Wskazuje się, że: [o] prowadzeniu przez posła lub senatora działalności gospodarczej „wspólnie” z innymi osobami nie można też mówić wówczas, gdy poseł lub senator jest wspólnikiem handlowej spółki osobowej, tj. spółki jawnej, komandytowej, partnerskiej lub komandytowo-akcyjnej, a więc gdy poseł lub senator działa $w$ ramach wspomnianej spółki w charakterze wspólnika [...] Nie wolno [...] zapominać, że działalność wspomnianych wspólników handlowej spółki osobowej jest $w$ pełni zarachowana na rzecz danej spółki $i w$ sensie prawnym jest ona działalnością tej właśnie spółki. Realizując de facto czynności składające się na prowadzenie działalności gospodarczej, wspólnicy handlowej spółki osobowej nie stają się bynajmniej podmiotami praw i obowiązków wynikających z tej działalności, gdyż punktem zarachowania dla tychże praw i obowiązków jest sama handlowa spółka osobowa, w której ci wspólnicy uczestniczą ${ }^{6}$. Co więcej, podkreśla się, że: [s]wojej własnej działalności gospodarczej $w$ znaczeniu normatywnym nie prowadzi tym bardziej taki wspólnik handlowej spółki osobowej, który nie jest uprawniony do jej reprezentacji, a więc który nie dokonuje w obrocie żadnych czynności prawnych za spółkę. Zakaz prowadzenia działalności gospodarczej „wspólnie z innymi osobami” występuje także w przepisach antykorupcyjnych dotyczących m.in. członków

4 A. Kidyba, Interpretacja art. 34 ust. 1 ustawy o wykonywaniu mandatu [w:] Status posła, cz. II, Wybór ekspertyz prawnych do rodziału 5 ustawy z 9 maja 1996 r. o wykonywaniu mandatu posła i senatora (Dz.U. z 2003 r. Nr 221, poz. 2199, ze zm.), Warszawa 2007, s. 305.

5 Ibidem, s. 306.

6 M. Szydło, Zakaz łączenia mandatu parlamentarnego. Studium prawne, WarszawaPoznań 2012, s. 222-223; zob. także W. Odrowąż-Sypniewski, Prowadzenie przez posła działalności gospodarczej (rolniczej) na terenach dzierżawionych od Skarbu Państwa [w:] Status posła w opiniach Biura Analiz Sejmowych (2007-2015), t. II, cz. 2, red. I. Galińska-Rączy, Warszawa 2015, s. 203. 
organów jednostek samorządu terytorialnego ${ }^{7}$. Przedstawiona wyżej wykładania jest przyjmowana także na gruncie tych przepisów ${ }^{8}$. Biorąc pod uwagę powyższe, należy zatem uznać, że działalność gospodarcza realizowana przez wspólników handlowej spółki osobowej jest działalnością gospodarczą prowadzoną przez samą spółkę, a nie działalnością gospodarczą wspólników. Tym samym fakt uczestniczenia w spółce komandytowej nie oznacza prowadzenia działalności gospodarczej w znaczeniu przyjmowanym na gruncie art. 34 ust. 1 u.w.m.p.s.

Inna kwestią jest natomiast to, czy aktywność posła komandytariusza w spółce komandytowej może zostać zakwalifikowana jako „zarządzanie” działalnością gospodarczą. W piśmiennictwie wskazuje się, że pojęcie „zarządzanie”: będąc często utożsamiane z pojęciem "kierowanie”, oznacza podejmowanie działań, których rodzaj jest mocno zdeterminowany i uwarunkowany przedmiotem zarzadu, a które działania polegaja na spowodowaniu funkcjonowania m.in. określonych rzeczy (obiektów, przedsiębiorstw) zgodnie z celem wyznaczonym przez zarzadzajacego lub też wytyczonym przez tego, kto ustanowit (wyznaczyt) zarzadzajacego i jest identyfikowane $z$ działalnością operacyjna, wykonywana bardzo często przez osoby „funkcyjne" (dyrektorów, kierowników, menadżerów) ${ }^{9}$. Można byłoby zatem mówić o naruszeniu zakazu zawartego w art. 34 ust 1 u.w.m.p.s. w sytuacji, kiedy poseł będący wspólnikiem handlowej spółki osobowej byłby jednocześnie uprawniony do prowadzenia spraw tej spółki. Jak wskazano powyżej, w przypadku spółki komandytowej, co do zasady dotyczy to komplementariusza. Komandytariusz nie ma prawa ani obowiązku prowadzenia spraw spółki, chyba że umowa spółki stanowi inaczej (art. $121 \$ 1$ k.s.h.). Jeżeli więc umowa spółki nie zawiera odmiennych postanowień, komandytariusz nie zarządza działalnością gospodarczą tej spółki.

Z informacji, które znalazły się u podstaw niniejszej opinii, wynika, po pierwsze, że nie będzie on wspólnikiem, ani też nie będzie pełnił żadnych funkcji (jako członek zarządu, prokurent) w spółce z o.o. będącej komplementariuszem spółki komandytowej i nie będzie miał żadnego wpływu na podejmowane przez komplementariusza decyzje. Ponadto nie będzie występował jako osoba uprawniona do reprezentacji spółki komandytowej (jako pełnomocnik), ani nie będzie jej prokurentem. W sytuacji takiej wydaje się, że nie może być on zakwalifikowany jako osoba zarządzająca działalnością gospodarczą na gruncie art. 34 ust. 1 u.w.m.p.s.

7 Zob. np. art. 4 pkt 6 ustawy o ograniczeniu prowadzenia działalności gospodarczej przez osoby pełniące funkcje publiczne oraz art. $27 \mathrm{~b}$ u.s.w.

8 S. Płażek, Art. $27 b$ ust. 1 [w:] Komentarz do ustawy o samorządzie województwa, red. P. Chmielnicki, Warszawa 2005, s. 193. Należy jednak odnotować, że w literaturze formułowany jest także pogląd odmienny, zob. np. P. Feczko, Petnienie funkcji wójta przez komandytariusza, „Samorząd Terytorialny” 2007, nr 1-2, s. 59-66; K. Święch, K. Kozłowski, Ograniczenia prowadzenia działalności gospodarczej przez członków organów jednostek samorządu terytorialnego, „Samorząd Terytorialny” 2003, nr 12, s. 28.

9 M. Szydło, Zakaz łączenia, op. cit., s. 230, i powołana tam literatura. 
Ponieważ zgodnie z art. $118 \$ 1$ k.s.h. komandytariusz spółki komandytowej może reprezentować spółkę jako pełnomocnik, potencjalnie poseł mógłby być objęty zarówno zakazem z art. 34 ust. 1, jak i art. 34 ust. 2 u.w.m.p.s. Biorąc jednak pod uwagę zastrzeżenie, że poseł nie będzie upoważniony do reprezentowania spółki jako pełnomocnik ani nie będzie występować w charakterze prokurenta, powyższe kwestie wydają się irrelewantne.

\section{Podsumowanie}

W przedstawionym we wstępie opinii stanie faktycznym brak jest przeszkód do łączenia mandatu posła ze statusem komandytariusza w spółce komandytowej.

\section{Bibliografia}

Feczko P., Pełnienie funkcji wójta przez komandytariusza, „Samorząd Terytorialny” 2007, nr $1-2$.

Kidyba A., Interpretacja art. 34 ust. 1 ustawy o wykonywaniu mandatu [w:] Status posła, cz. II, Wybór ekspertyz prawnych do rozdziału 5 ustawy z 9 maja 1996 r. o wykonywaniu mandatu posła i senatora (Dz.U. z 2003 r. Nr 221, poz. 2199, ze zm.), Warszawa 2007.

Odrowąż-Sypniewski W., Prowadzenie przez posła działalności gospodarczej (rolniczej) na terenach dzierżawionych od Skarbu Państwa [w:] Status posła w opiniach Biura Analiz Sejmowych (2007-2015), t. II, cz. 2, red. Galińska-Rączy, Warszawa 2015.

Płażek S., Art. 27b ust. 1 [w:] Komentarz do ustawy o samorządzie województwa, red. P. Chmielnicki, Warszawa 2005.

Szydło M., Zakaz łączenia mandatu parlamentarnego. Studium prawne, Warszawa-Poznań 2012.

Święch K., Kozłowski K., Ograniczenia prowadzenia działalności gospodarczej przez członków organów jednostek samorządu terytorialnego, „Samorząd Terytorialny” 2003, nr 12. 